\title{
Analysis on the Application of Intertextuality and Context Theory in Humorous Discourses
}

\author{
Xinyue Zhang \\ Department of Humanities and Social Science, Heilongjiang Bayi Agricultural University, Daqing, China
}

Email address:

xinyuezhang201805@163.com

\section{To cite this article:}

Xinyue Zhang. Analysis on the Application of Intertextuality and Context Theory in Humorous Discourses. Communication and Linguistics Studies. Vol. 4, No. 2, 2018, pp. 27-31. doi: 10.11648/j.cls.20180402.11

Received: April 19, 2018; Accepted: May 14, 2018; Published: May 29, 2018

\begin{abstract}
Intertextuality, although emerged in the field of literary criticism, attracts scholars' much attention in discourse analysis in the field of linguistics. It has certain practical significance in analyzing law documents, advertisements, academic papers, news reports and other types of discourses. Humor, as a pervasive phenomenon in human society and an interdisciplinary research subject, has attracted scholars' much attention from different fields. This paper aims to explore how intertextual resources are appropriately applied in humorous discourses. As intertextuality at the same time brings at least two contexts of each text, context theory will further help to analyze how intertextual relations in certain context lead to humorous effect.
\end{abstract}

Keywords: Humorous Discourse, Intertextuality, Context Theory

\section{Introduction}

Humor has been extensively studied in humanities within psychology, philosophy, sociology, anthropology, esthetics and other fields. There are three most typical theories about humor research: the superiority theory, the relief theory and the incongruity theory. Humor especially verbal humor as one of the distinctive attributes and a communicative competence possessed by human beings is created and conveyed indispensably with the help of language. Therefore, it is inevitable to study humor within the scope of linguistics.

It has been a long history since the beginning of the research on intertextuality. Intertextuality originally begins in the field of literary criticism. And then scholars expand the research to many other fields, for instance, the linguistic field. With the development of intertextuality in linguistic field especially in discourse analysis on one hand and on the other hand, because of the intertextual nature of humorous discourse, the study on humor from the perspective of intertextuality becomes an inevitable trend. Norrick [1] once assumes that intertextual humor is based on an original text and perceivers have to know some intertextual knowledge in order to appreciate humors. From his study, we can see that it is inevitable and feasible to study humor from the perspective of intertextuality.

In addition, intertextuality concerns more than two texts including the previous text or source text and the present text or the target text, while at the same time, it brings at least tow contexts of each text which also have an intertextual relationship. It is therefore assumed that context theory would be effective to help further analyze humor from the perspective of intertextuality. This paper will be a practical and creative attempt in analyzing how to generate and appreciate humorous effect from this point of view.

\section{Intertextuality and Context Theory}

The theory of Intertextuality can be traced back to Saussure's linguistics. Saussure [2] regards language as a system composed of signs which are different from each other. The meanings of linguistic signs can be achieved through interactions with other signs. He considers the sign as a whole, in a sign, what matters more than any idea or sound associated with it is what other signs surround it. The concept of intertextuality, in this sense, resembles Saussure's semiotic theory.

Bakhtin [3] once said: "I live in a world of others' words." He believes that all texts possess dialogic nature and everything in the world is a text. Bakhtin's dialogism theory emphasizes the social and historical contexts within which language is used. It is based on his theory that Kristeva introduced the term intertextuality in her book in 1969. To some extent, Kristeva's intertextuality is the reformation and 
development of Bahktin's dialogism. She absorbs both Saussure's view of linguistic signs and Bahktin's dialogism. According to Kristeva [4], she says that "every text is constructed as a mosaic of citations; every text is the absorption and transformation of other texts." Though Kristeva is the first to introduce the term, intertextuality, it is an abstract and broad term which is difficult for people to understand and does not attract widely-received attention. Since intertextuality first emerged in the field of literary criticism, it has attracted many theorists of literature such as Barthes. It was Barthes who studies this concept later that makes great contributions to its development and makes it popular receive great attention. It was not until late 1980s that intertextuality began to attract Chinese scholars' attention, among whom, Qin Haiying and Xinbin are the representatives. They make great contributions to both the theoretical research and practical research.

Though the concept of intertextualtiy was first introduced in literary field, especially in the literary criticism, it develops quickly into other fields. It attracts much attention from scholars in linguistic field and then gradually be popular in translation research, discourse analysis, critical linguistics and pedagogical research on foreign language learning. There are also practical studies on discourses such as law documents, advertisements, academic papers and news reports from the perspective of intertextualtiy.

Different scholars have different standards to categorize classification of intertextuality. Generally speaking, intertextuality can be seen either from narrow or broad sense. Narrow intertextuality concerns relationships between the present text and other texts which can be proved to be existed in the present text. Intertextuality in a broad sense refers to relations between present text and any knowledge, code or semantic manifestations which can endow meanings to the present text. In this paper, the author will adopt Xinbin's classification who proposes to classify intertextuality into specific intertextuality and generic intertextuality from readers' and analysts' perspectives [5]. Specific intertextuality refers to the phenomenon that a text contains others' utterances with specific and clear sources. Generic intertextuality refers to the mixture of different styles or genres.

Malinowsky [6], the British anthropologist first puts forward that context refers to the total environment in which language is used and in which a text is folded, and it helps people understand utterance meaning accurately. Later Firth, the representative of London School further develops Malinowsky's idea about the context and introduces three factors including properties of participants, the relevant objects and the effect of the verbal action. Based on Firth's study, Halliday [7] together with McIntosh and Strevens put forward a new way to interpret context. They propose the three variables of context which are field, tenor and mode. The three variables serve to interpret the context of a text, the environment in which meanings are being exchanged.

Intertextuality refers to the relationship of mutual penetration among texts, no text stands alone but is interlinked with the tradition that came before it and the context in which it is produced [8]. Any context is indispensable to any text and intertextuality indicates at least two contexts corresponding to each text. It is supposed that the present context of the present text contradicting or complementing with the previous context of the previous text might lead to humorous effect. The following parts will give a detailed description of this view.

\section{Specific Intertextuality Applied in Humor}

According to Xinbin's classification, specific intertextuality involving reference, cliché, quotation and parody will be illustrated and detailed description of how each form of specific intertextuality lead to humorous effect will be presented in the following parts.

\subsection{Reference}

Intertextuality infiltrates everything we say or write. Our utterance or texts respond to previous utterances or texts, and they reflect, re-contextualize, or even re-accentuate them via implicit or explicit references [9]. Norrick (1989:117) assumes that intertextuality occurs any time one text suggests or requires reference to some other identifiable texts or stretches of discourses, spoken or written. Reference as a basic form of specific intertextuality is used to specify the source text and constructs the intertextual relations between the source or previous text and the target or present text. For example:

Teacher: Elmer, who won the War of the Roses?

Elmer: It's not over yet, but so far the bugs are winning.

In this short conversation that happens between a teacher and a student, the War of the Roses mentioned by the teacher actually refers to the war which was waged intermittently between the House of Lancaster and the House of York in history lasting about thirty years. The flag of Lancaster showed a red rose, and the flag of York showed a white one, so the struggle between them are known as the Wars of the Roses. However, the student misunderstands what the teacher refers to and takes it as the war between bugs and roses thus make people laugh.

Sometimes the author does not need to introduce the whole previous text in the present text, instead, only mentioning some main parts of the previous text to indicate its whole meaning and context. Let's take another example: At the beginning of the $90^{\text {th }}$ Oscar Award ceremony, the host reminds the guests not to stand up right away when they hear their names being called which make people laugh loudly. However, if the audience do not know what happened in the $89^{\text {th }}$ Oscar Award ceremony, the humorous effect could not be achieved. Actually the humor is appreciated by the audience since all of them know that the host actually refers to the mix-up first happened in Oscar history that the wrong envelop had been opened while an award was being announced. The host and the audience share the same intertextual background so that the humorous effect can be generated and then appreciated.

In order to discuss how specific intertextuality is applied in 
humor and lead to humorous effect, the following examples are mainly collected from the popular sitcom Friends with abundant humorous discourses. Though Friends is an old sitcom, it is still popular in China. The following example is an extract taken from Friends:

Waiter: So, would you like any dessert?

Michael: No! No dessert, just a check, please.

Rachel: Oh, you're not having fun, are you?

Michael: No, no, I am, but only because for the last hour and a half I've been playing the movie Dinner in my head. (Laugh).

The conversation above happens when Rachel and Michael are going to leave the restaurant and Rachel finally realizes that Michael has a boring time with her. She feels sorry but Michael responses euphemistically by reference to the movie Dinner in which it tells a story about a group of students who share their happiness and sorrow in a dinner. Thus the present text is about Rachel's date with Michael; the source text is about the students' sharing their life experience to each other in the movie. The two contexts of these texts own different agent roles which belong to different tenor of discourse and complement with each other thus lead to humorous effect.

Obviously with the examples above, reference as type of specific intertextuality is one of the effective ways to generate humorous effect. Allusion is also an effective way to build the intertextual relationship and a special kind of reference which usually refers to well-known people or important events in history. As they are familiar to both speaker and hearer or writer and reader, the humor in which allusion is applied is much likely to be appreciated by both sides.

\subsection{Cliché}

Cliché as a form of specific intertextuality refers to words or expressions that are frequently used in a certain field and it works a lot in helping to generate humorous effect. The example taken from Friends is as follows:

Chandler: No way!

Monica: I'm telling you, she went to the airport, and she's gonna go for it with Ross!

Phoebe: Oh my god. This is huge. (laugh) This is bigger than huge. This is like, all right, what's bigger than huge?

Joey: Um, this?

Phoebe: Yes.

This scene happens when Rachel has gone to the airport to declare love to Ross and Monica excitedly informs everyone about what Rachel has done. Phoebe has just changed Chandler and Joey's hairstyle but unnoticed by Monica. "This is huge." is often mentioned in a news report. Here Phoebe uses the utterance to respond to Monica's notification of Rachel's braveness. The nature of the social activity, the field of discourse in the two related contexts contradicts with each other which lead to humorous effect.

Another example about cliché:

Monica: Joey speed it up!

Joey: I'm sorry, it's the pigs. They're reluctant to get in the blankets!

Phoebe: Monica, how did this happen? I thought you had this all planned out.

Monica: Do you want me to cry? Is that what you want? Do you wanna see me cry?

Phoebe: Sir! No sir! (laugh)

Monica is in a hurry. She is running out of time to prepare for a wedding reception so she asks Phoebe and Joey to do her a favor. Phoebe wonders how did this happen. However, as Monica has no time to explain to her, she just responds using three rhetorical questions aggressively like a commander which makes Phoebe give a quick answer, "Sir! No sir." by instinct. "Sir" as a cliché in the police field reminds the audience the context of policemen addressing or responding to their commanders. Phoebe and Monica are intimate friends. Thus the related contexts of two texts belong to different fields of discourse which lead to humorous effect. Cliché as a form of specific intertextuality could generate humorous effect when it is not used in its original field.

\subsection{Quotation}

Quotation as another intertextual form means quoting others' words or sentences from the previous texts. The quoted words or sentences are either exactly the same as the whole source text or a variation of the source text. Let's see examples taken from Friends:

Phoebe: So...now...What about with Mike's mom?

Rachel: Oh, with the mother, just...just constantly tell her how amazing her son is. Take it from me, mom loves me. Ross's mom one tome actually said I'm like the daughter that she never had.

Monica: She said what?

Phoebe: That' she's like the daughter she never had. (Phoebe points at her ears.) Listen!

In this scene, Phoebe wants Rachel and Monica to give her some advice about how to please her fiancé's parents. Rachel, showing off her adorable figure, tells Phoebe the experience she has when she met her boyfriend, Ross's mother. Rachel quotes what Ross's mother and says, "I'm like the daughter that she never had. Hearing what Rachel said, Monica, Ross's sister is unbelievable what her mother said. So Monica asks, "She said what?" which in fact is not a real question but to show her surprise. However, Phoebe misunderstands Monica's reaction and quotes what Rachel said which makes Monica speechless and the audience laugh.

Another example using quotation in Friends:

Monica: Ross, come sign this birthday card for dad. Rich is gonna be here any minute.

Chandler: Oooh, Rich is going to the party too, huh?

Monica: Well, he's my parents' best friend, he has to be there.

Joey: Oh, is today the day you're gonna tell them about you two.

Monica: Yeah. It's my dad's birthday, I decided to give him a stroke.

Phoebe: No, I think you should tell them.

Monica: No, I don't even know how serious he is about me. Until I do, I'm not telling them anything.

Ross: I don't know, I don't think mom and dad would mind. 
Remember when you were 9 and Richard was 30, how dad used to say, "God I hope they get together". (Laugh)

The friends are talking about whether Monica should tell her parents about her new boyfriend who happens to be her parents' best friend and is much older than her. Ross, Moinca's big brother quotes their dad' words which is said when Monica is very young. The quoted words, the previous text given by Monica's dad supposes to mean he hopes Monica and Richard can get along well as friends when she was a kid. The present text quoted by Ross in the current situation supposes to mean Monica and Richard become lovers. The tenor of discourse in different contexts aroused by intertextual relation contradicts with each other thus giving rise to humorous effect.

\subsection{Parody}

Parody is a particular type of intertextuality, namely a text's reliance upon the meaning structure of other texts. It is broadly defined as a form of imitation. [10] It not only imitates the content but also the structure of the original text. The use of parody is like making a new wine that taste like the old but has a slightly lethal effect. We assume that new expressions created in this way can arouse the audience's attention and also achieve humorous effect. Let's take an example taken from Friends:

Joey: Real estate, huh? Humm...

Monica: Oh, and you know who's selling a great apartment? Richard!

Chandler: Oh, and you know whose knowledge of her ex-boyfriend is shocking? Monica! (Laugh)

In this scene, Joey has made a fortune and he wants to ask Monica and Chandler whether they have some ideas about investment. Monica suggests that Joey should consider the real estate investment and her ex-boyfriend Richard happens to have an apartment for sale. So she said excitedly "Oh, and you know who's selling a great apartment? Richard!”. We know that Monica and Chandler are in a relationship now. Hearing what Monica said, Chandler parodies the structure of Monica's utterance to show his angriness and jealousy that his girlfriend is still in touch with her ex-boyfriend. It is Chandler's imitation of the structure of previous utterance that leads to humorous effect.

\section{Generic Intertextuality Applied in Humor}

According to Xinbin's classification, generic intertextuality refers to the mixture of genres or styles. Bhatia [11] regards genre as a communicative event with its purposes regularly sharing by members of a certain professional or academic community. In other words, genre is a means for a special group of people to communicate. Style concerns the manners of utterance or ways to express one's idea through language. It is assumed that the proper use of generic intertextuality could lead to humorous effect. The following examples taken from Friends will present how generic intertextuality is applied in humor in detail.
Phoebe: I have just a few questions to ask, so I'll get out my official forms.

So question one: You were married to Frances' daughter, Lily. Correct?

Frank Buffay: Yes, I was.

Phoebe: Question two: Did that marriage end: A: happily? B: Medium? C: in the total abandonment of her and her two children?

Frank Buffay: I guess then I would have to say C.

Phoebe: OK, total abandonment. Reasons for abandonment: A: Top-secret government work. B: Amnesia. or C. You're just a selfish, irresponsible bad bad man.

The conversation happens between Phoebe and her father who has abandoned her when she was a little girl. She wants to make sure the man is her father and ask why he abandoned her, but it was a little embarrassed to start to ask. So Phoebe here takes a genre of relatively official questionnaire including several questions to ask her father. The genre of casual and informal chat between a daughter and a father mixed with a genre of professional and formal questionnaire lead to humorous effect.

Joey: Sup? Sup dude?

Chandler: (putting his hands up) Take whatever you want, just please don't hurt me.

Joey: So you're playing a little Playstation, huh? That's whack! Playstation is whack! Come on, am I 19or what?

Chandler: Yes, on a scale from 1 to 10,10 being the dumbest a person can look, you are definitely 19 .

This conversation happens between Joey and Chandler who are best friends for years. Joey is an actor who is already 31 years at that time but in order to prove he can still play a 19-year-old, he tries to dress and speak like a 19-year- old boy. Words like "Sup", "Sup, dude" and "That's whack" are informal and are always used by teens. Two different styles of languages are mixed in the present text thus generic intertextuality generates humor and makes the audience laugh.

\section{Conclusion}

To sum up, intertextuality is one of the characteristics of humor and plays an important role in generating and appreciating humor. Context theory can help analyze the mechanism of generating humorous effect. In addition, in order to achieve humorous effect, you have to know whether others who you want to humor know the intertextual resources you mentioned. That is to say both sides have to share common intertextual information. In cross cultural communication, it is even more important to pay attention to the intertextual information which is not shared by people from different cultures which may cause misunderstanding thus needs further research.

\section{References}

[1] Norrick, N. R. (1989). Intertextuality in Humor. International Journal of Humor Research 2(2):117-139. 
[2] Saussure, F. (2012). Course in General Linguistics. Beijing: Foreign Language Teaching and Research Press.

[3] Bakhtin, M. (1981). The Dialogic Imagination: Four Essays. London: University of Texas Press.

[4] Kristeva, J. (1969). Semiotics: Researches for Semantic Analysis. Paris: Seuil Press.

[5] Xinbin (2005). Critical Linguistics: Theory and Application. Shanghai: Shanghai Foreign Language Education Press.

[6] Malinowsky, B (1923). "The problem of meaning in primitive language", in supplement to C. K. Odgen and I. A. Richards, The Meaning of Meaning. London: Kegan Paul.

[7] Halliday, M. K. and Hasan, R. (2012) Language, Context and
Text: Aspects of Language in a Social-semiotic Perspective. Beijing: World Publishing Corporation.

[8] YAN Jiansheng (2017) Information Construction of News Discourse under the Perspective of Intertextuality. Studies in Literature and Language Vol. 14, No. 1, pp. 18-21.

[9] Villy Tsakona (2018) Intertextuality and/in Political Jokes. Lingua 203 (2018)1-15.

[10] Gray, J. (2006). Watching with the Simpsons: Television, parody, and intertextuality. London: Routledge.

[11] Bhatia, V. K. (2010). Interdiscursivity in Professional Communication. Discourse \& Communication Vol. 21 No. 1, pp. 32-50. 